\title{
Svět je symbolická interakce: symbolický interakcionismus jako východisko výzkumu teatrality veřejných událostí
}

\author{
The World As a Symbolic Interaction: Symbolic Interactionism As \\ a Starting Point For the Research of the Theatricality of Public Events
}

Lukáš Kubina / Martina Musilová

\begin{abstract}
Abstrakt
Studie představuje teorii a metodologii symbolického interakcionismu a její vztah k výzkumu teatrality veřejných událostí. Sociologický směr symbolický interakcionismus ovlivnil celou řadu metodologických přístupů, největší vliv měl logicky v sociálně-vědních oborech, které pracují se symbolickou povahou empirie. Zároveň se ale tento směr uplatnil i v uměnovědných oborech, a to díky schopnosti interpretovat symbolickou povahu jednání, jeho procesuálnost a časoprostorový charakter. Symbolický interakcionismus tak, jak ho definoval H. Blumer, byl zásadně ovlivněn filozofií pragmatismu a sociální psychologií G. H. Meada, proto je jim věnována první část studie. V druhé části textu jsou představena základní teoretická a metodologická východiska symbolického interakcionismus, která jsou demonstrována na př́kladu veřejné události (setkání občanů s prezidentem ČR v Brně v roce 2013), které se autoři studie účastnili v rámci terénního výzkumu.
\end{abstract}

\section{Klíčová slova}

symbolický interakcionismus; pragmatismus; teatralita; kulturní performance; Chicagská škola; interakce; interpretace

\begin{abstract}
The paper presents the concept of symbolical interactionism, its theoretical background, adjoining methodologic tools, and its relation to the issue of theatricality of public events. The symbolic interactionism, a sociology-based concept stating a symbolical nature of empirical knowledge, influenced a great number of strands of thinking both in social sciences and humanities. At the same time, the concept gained recognition also in Theatre and Performance Studies for its ability to grasp the symbolic nature of human interaction, its processuality, and temporal-spatial aspect. First part of the study is devoted to the philosophy of pragmatism and George Herbert Mead's social psychology that deeply influenced Blumer's definition of the symbolic interactionism. The second part comprises the basic theoretical and methodologic background of symbolic interactionism demonstrated on the example of filed research carried out by the authors, citizen meeting with Czech President in Brno in 2013.
\end{abstract}




\section{Keywords}

symbolic interactionism; pragmatism; theatricality; performativity; cultural performance; Chicago school; interaction; interpretation

\section{Úvod - Teatralita v evropském i mimoevropském kontextu}

V roce 2014 vyšlo číslo časopisu Theatralia věnované z velké části prezentaci výzkumů teatrality veřejných událostí, prováděných na KDS FF MU od roku 2010. Teatralita je zde definována předně z hlediska německé teatrologie, která se výzkumy tohoto typu zabývá již od 70. let 20. století. Nejvýrazněji teorii teatrality v 90. letech minulého století rozpracovala Erika Fischer-Lichte z berlínské Freie Universität, která vychází z širšího pojetí divadla inspirovaného pracemi Nikolaje N. Jevrejnova. Tento přístup uplatnila v rámci rozsáhlého projektu zaměřeného na výzkum událostí, jež byly nahlíženy a analyzovány pomocí sociologicko-teatrologického pojetí divadla jako „kulturního modelu“ (FISCHER-LICHTE 2005a).

Cílem této studie je představit sociologický směr symbolický interakcionismus, který se zabývá jednáním člověka v každodenních situacích a který nabízí odlišné teoretické a metodologické př́istupy, jež mohou obohatit teorii teatrality berlínské teatrologie. Naší motivací je rovněž ukotvit symbolický interakcionismus v současné české teatrologii, která s jeho východisky často nevědomky pracuje; nejčastěji prostřednictvím prací amerického sociologa Ervinga Goffmana, známého v českém prostředí díky překladu knihy Všichni hrajeme divadlo (The Presentation of Self in Everyday Life, 1956/1959; česky 1999). V první části studie se proto budeme věnovat podhoubí, z něhož symbolický interakcionismus vyrůstá, tj. americké pragmatické filozofii a sociální psychologii George Herberta Meada. V druhé části pak představíme základní premisy symbolického interakcionismu a pokusíme se je demonstrovat na konkrétním příkladu z politického mítinku z roku 2013, jehož jsme se v rámci terénního výzkumu účastnili.

Naše potřeba obohatit metodologický přístup podněty z oblasti sociologie, jak je nabízí symbolický interakcionismus, vychází z částečně kritického zhodnocení definice teatrality předložené Erikou Fischer-Lichte. V jejím pojetí teatrality hraje klíčovou roli rozšíření fenoménu divadla o oblast mimoestetickou, ve které rovněž nachází divadelní prvky. Fischer-Lichte vychází z teorií Nikolaje Jevrejnova, který na počátku 20. století vymezil teatralitu „vně okruhu působnosti divadla jako autonomního umění anebo jako sociální instituce“ (FISCHER-LICHTE 2005a: 5). Teatralita je pak chápána jako tvořivá proměna světa a definována jako „před-estetický instinkt“ (FISCHER-LICHTE 2005a: 5), „který je jakožto kulturotvorný a kulturní dějiny pohánějící princip základem a podmínkou možnosti nejen umění, nýbrž i náboženství, práva, mravů a politiky. “ (FISCHER-LICHTE 2005b: 132) Divadlo pojímané jako antropologická kategorie umožňuje podle Fischer-Lichte zkoumat čtyři základní aspekty teatrality, jež nacházíme 
v mimoestetických projevech člověka, resp. v kulturních performancích ${ }^{1}$. Jsou jimi aspekty performance, inscenace, tělesnosti a vnímáni (FISCHER-LICHTE 2005b: 132). Vedle tradičního aspektu inscenace, jenž umožňuje zkoumat výrazovou složku kulturních performancí (kostým, scéna, mizanscéna, dramaturgie, scénář apod.), umožňuje antropologické pojetí divadla jakožto „kulturního modelu“ zkoumat podoby divadelní komunikace v mimoestetické oblasti (vztah herce a diváka, diváků mezi sebou apod.) a rovněž fenomény spjaté s procesualitou a časovým charakterem kulturních performancí (situace „ted” a tady“, efemérnost performance apod.).

Teatralita, definovaná berlínskou teatrologií pod vedením Fischer-Lichte je vymezena pomocí ozvláštňujícího, tj. estetizujícího principu - v polaritě estetické a mimoestetické funkce ${ }^{2}$, jenž umožňuje „stupňování a intenzifikaci proměn života“ (CARLSON 2002: 246). V jádře Jevrejnovova přístupu totiž dominuje jako hlavní princip tvưrčí instinkt proměny a transformace světa (CARLSON 2002: 246), který nám poskytuje vytrhnutí se „z banální kontinuity společenského řádu a každodenního života“ (GIESEN 2006: 327). Jak píše sám Jevrejnov: „Prvobytný člověk vnáší do svého života divadelnost, protože jenom tehdy život získává nějaký smysl, stává se jeho životem, něčím, co může milovat!“ (JEVREJNOV 2014: 126) Přestože se Jevrejnov snažil vymezit proti estetizujícímu pojetí divadelnosti ${ }^{3}$ a divadelní instinkt člověka definuje jako předestetický, setrvává v dichotomii pojmů estetický - před/mimoestetický.

Takto rozpracované (mimo)estetické východisko teatrality je metodologicky výhodné pro evidenci divadelních fenoménů obsažených v kulturních performancích a pro samotné uvědomění si pole výzkumu. Dalším kladem tohoto přístupu je vědomá práce s perspektivou vnímání. Divadlo samo totiž, na rozdíl např. od filmu, využívá dvojí modus vnímání situace - ztotožnění a distancování. ${ }^{4}$ To je umožněno jednak zdvojením herce ve

1 Termín kulturni performance (cultural performances) poprvé použil antropolog Milton Singer v roce 1959. Podle Singera zahrnují kulturní performance takové události, jako jsou hry, koncerty, přednášky, modlitby, rituální čtení, recitace, rituály, obřady a svátky, které západní civilizace klasifikuje jako náboženské a rituální (SINGER 2003: 61). Antropolog Victor Turner definuje kulturní performance jako události různých žánrů, které povstávají ze zkušenostního pole sociálního dramatu (social drama) a zpětně ovlivňují obrysy sociálních interakcí v každodenním životě (TURNER 1980: 158; TURNER a TURNER 1982: 48). Kulturní performance a jejich pozici v rámci výzkumů současné teatrologie definuje v knize Divadelní věda německý teatrolog Andreas Kotte (KOTTE 2010: 100-101). V současné době pracuje s tímto termínem v sociálních vědách především kulturní sociologie, jejímž předním reprezentantem je profesor z Yale University Jeffrey C. Alexander. V kulturní sociologii se používá také termín sociálni performance.

Termín kulturní performance v této práci chápeme ve své podstatě jako neutrální označení jakékoliv veřejné (kulturní) události, at už každodenní nebo přesahující každodenní život. Obecně se kulturní performance vyznačují časovostí, záměrností a participací diváků.

2 Viz definice mimoestetické funkce Petra Bogatyreva ve studii „Mimoestetické funkce lidového divadla“ (BOGATYREV 1950: 30-52). Bogatyrev ve své definici estetické a mimoestetické funkce vychází ze strukturalistického pojetí Jana Mukařovského.

3 Svou roli v Jevrejnově konceptu hraje i snaha vymezit se vůči modernistickým vizím divadla-chrámu (R. Wagner, V. Ivanov a další) a vizi umění, jež nahradí náboženství sekularizované evropské společnosti na počátku 20. století.

4 Tato specifická vlastnost recepce divadelního zobrazení není dána pouze psychologií vnímatele, ale je fundamentální pro samotný způsob divadelního zobrazení, tj. zdvojením herce a jeho identity v roli. Film naopak distanci herce a jeho „bytí v roli“ pokud možno stírá: „Pokud fotografie reprodukuje realitu, posiluje reálný ráz lidí a věcí, které předvádí pohledu. Rozlamuje rámec jeviště, likviduje scénu, zasazuje diváka 
hře (herec hrající roli) ${ }^{5}$, jednak vědomím divadelní konvence, která sama přináší estetický prožitek a poznání. Dalším inspirativním momentem, který přináší „divadelní“ analýza kulturních performancí, je vědomí víceperspektivního vnímání, které je dané fenoménem diváctví. Divadelní divák zpravidla vnímá jak hru na scéně, tak ostatní diváky a vcituje se rovněž do jejich vnímání. Perspektivy vnímání se zde, brechtovsky řečeno, zmnožují. ${ }^{6}$

Koncepce teatrality Fischer-Lichte ovšem nepředstavuje jediné východisko pro výzkumy nedivadelních oblastí. Německojazyčná teatrologie studuje koncepty teatrality a performativity dlouhodobě, kromě Freie Universität se jí zabývají teatrologové i na řadě jiných univerzitních pracovišt (Berlín - Humboltova univerzita, Lipsko, Bern). ${ }^{7}$ Významné místo mezi nimi představuje koncepce Joachima Fiebacha, akcentující interaktivitu a symbolický ráz lidského jednání v divadelní i mimodivadelní komunikaci. $\mathrm{Na}$ Fiebachův koncept teatrality a performativity navazoval v českém prostředí Jan Roubal, jenž ve své studii „Interaktivita jako dimenze teatrality života a živosti divadla“ definuje pojem interaktivita jako strukturní prvek teatrality. Původně sociologický pojem interaktivita tak byl vřazen do současné české teatrologie a obohatil (mimo)estetický prŕstup Eriky Fischer-Lichte o podněty amerických performačních studií, které se rozvíjely od 60. let minulého století a vedly $\mathrm{k}$ tzv. performativnímu obratu.

Na rozdíl od evropské teatrologie byl tzv. performativní obrat na americkém kontinentě iniciován antropologickými a sociologickými výzkumy. Koncept performativity Richarda Schechnera a koncept sociálního dramatu Victora Turnera nasměroval v 70. a 80. letech minulého století výzkumy kulturních performancí směrem k bádání v oblastech rituálu a svátku. V současné době se trend ve výzkumu teatrality v německém i českém prostředí ubírá více směrem $\mathrm{k}$ sociálně a antropologicky zaměřenému typu bádání. Zásluhu na tom má především již zmíněný Victor Turner a zvláště pak Erving Goffman. Přínos Goffmanovy knihy Všichni hrajeme divadlo spočívá zvláště v tom, že nevídaně srozumitelnou formou s využitím divadelní terminologie ${ }^{8}$ osvětluje principy chování jedinců v každodenních interakcích. Goffman se zabýval způsoby, jakými se aktéři prezentují před ostatními účastníky interakce a jak kontrolují dojem, který o sobě vytvářejí. Ostatně problematika výzkumu teatrality každodennosti se ukazuje jako zásadní. Slovy Arno Paula (Theaterwissenschaft als Lehre vom theatralischen Handeln, 1971; česky 2005) je symbolické jednání konstitutivním momentem divadla, potažmo jakékoliv kulturní události. Bez jejího pochopení není možné plně analyzovat komplexnějšś kulturní performance, jako jsou politické mítinky, folklorní slavnosti, soudní líčení či nejrůznější občanské a náboženské rituály.

doprostřed událostí, aniž by mu jakkoli připomínala jeho vzdálenost, která je podmínkou jeho prožitku. Film dospívá až k iluzi herce, jenž ztělesňuje sebe sama. [...] Jde mu o iluzi fyzické spolupřítomnosti. Herec nesmí dát najevo, že ví o pohledu diváka, který na něm spočívá, a divák musí zapomenout na to, že je divákem a posluchačem." (PLESSNER 2008: 22-23)

5 Viz Eugen Fink Oase des Glücks (1957; česky Oáza štěstí, 1992).

$6 \quad$ S tímto principem např. pracuje při své dramaturgické analýze E. Goffman.

7 Viz (ROUBAL 2005).

8 Viz role a scéna, případně modifikace divadelních konceptů, jako jsou jeviště a zákulisí, respektive přední a zadní region (GOFFMAN 1999). 


\section{Východisko symbolického interakcionismu - americký pragmatismus}

Jak již bylo zmíněno, v české teatrologii nejsou některé principy symbolického interakcionismu díky E. Goffmanovi zcela neznámé. Odkazy k symbolickému interakcionismu můžeme nalézt i v performačních studiích Richarda Schechnera, s nimiž je česká teatrologická veřejnost dostatečně seznámena. ${ }^{9}$

Symbolický interakcionismus významně ovlivnil způsob uvažování o kulturních performancích a s trochou nadsázky se dá říci, že stál u kořenů tzv. performativního obratu v humanitních vědách ${ }^{10}$. V době svého největšího rozvoje v padesátých a šedesátých letech 20. století se od ostatních sociologických směrů lišil tím, že zdůrazňoval význam jednání jedince, každodennost a symbolickou povahu jednání. Zároveň se kriticky stavěl k pozitivistickému výkladu společnosti a ke koncepci dominantního vlivu společnosti a její struktury na jedince. Filosoficky vychází tento sociologický směr z filosofie pragmatismu, který nově definoval symbolický význam, symbolické jednání a jeho dopad na život člověka a orientoval se na budoucnost a zacílení jednání a sociálních aktů.

\section{Americký pragmatismus a jeho hlavní představitelé}

Americký pragmatismus je filosofický směr formovaný v USA od 70. let 19. století. Je chápán jako jeden z proudů filosofie života, respektive činného života, který reagoval na společensko-kulturní proměny moderní společnosti. Vyvíjel se ve specifických podmínkách modernity, urbánním prostředí Bostonu a Chicaga na přelomu 19. a 20. století (VIŠŇOVSKÝ 2014: 15). Pragmatismus je prvním moderním filosofickým směrem, který chtěl překročit některé postuláty racionalistické filosofie novověku (např. karteziánský dualismus). Podstatnou roli při jeho formování hrálo rovněž protestantské prostředí USA ${ }^{11}$. Základními rysy pragmatické filosofie jsou akcentování významu jednání a životní praxe, jakožto zdroje poznání a zkušenosti, a odmítání redukce zkušenosti na proces vnímání objektů (HROCH 2003: 15).

Nejvýznamnějšími představiteli amerického pragmatismu byli Charles S. Peirce (18391914), William James (1842-1910), John Dewey (1859-1952), F. C. S. Schiller (1864-1937; působil v anglickém Oxfordu), Josiah Royce (1855-1916) a George Herbert Mead (18631931). ${ }^{12}$ Ačkoliv se pragmatismus vyvinul do řady proudů, za nejvýznamnější je třeba považovat dvě školy. První je spojena s Harvardovou univerzitou, kde působil W. James

9 Viz Schechnerova studie „From Ritual to Theatre and Back: The Structure/Process of the Efficacy-Entertainment Dyad“ (1974; slovensky „Od rituálu k divadlu a zpět“, in Performancia: teórie, praktiky, rituály, 2009).

10 Performativní obrat v teatrologii definovala Erika Fischer-Lichte ve své knize Estetika performativty (Mníšek pod Brdy: Na konári, 2011). Tento paradigmatický posun probíhá od 60. let minulého století prakticky dosud v různých humanitních a společenských vědách, viz performativní obrat ve filosofii jazyka (Kenneth Burke, John L. Austin, John Searle), v kulturní historii (Peter Burke), v antropologii (Victor Turner, Clifford Geertz), v sociologii (Pierre Bourdieu, Jeffrey C. Alexander), v gender studies (Judith Butler).

11 Viz zaměření na životní praxi a orientace na budoucnost.

12 Ohlasy amerického pragmatismu v české filosofii a kultuře najdeme zvláště v meziválečném období (ČAPEK 1918) a (VOROVKA 1929). Stranou zájmu ale nezůstává pragmatismus ani v současnosti (BÍLEK 2016). 
a kde se pragmatici zabývali náboženstvím a intuitivními metodami. Druhá škola je spojena s Chicagskou univerzitou, na které působili J. Dewey a G. H. Mead. Chicagská škola byla zaměřena na experimentální metody a rozvíjela sociologické výzkumy městského prostředí a každodenního života (HÖFFDING a KRÁL 1947: 281). ${ }^{13}$

\section{Jednání}

Za stěžejní koncept amerického pragmatismu můžeme považovat jeho důraz na lidské jednáni (action), v jehož procesu člověk nabývá zkušenost. Dewey ve svém antidualistickém pojetí, kterým chtěl překlenout oddělení teorie (theoría) od praxe (praxis), ustanovené řeckou klasickou metafyzikou a v novověku rozvíjeným karteziánstvím, tvrdí, že nemůžeme určit význam myšlení, pokud jej abstrahujeme od jednání (VIŠŇOVSKÝ 2014: 29). Podobně James zastává názor, že význam myšlenky lze určit podle toho, k jakému jednání povede, respektive, že všechny skutečnosti mají vliv na naše jednání a tento vliv je jejich smyslem pro nás (JAMES 1918: 31).

Podle pragmatiků je tedy poznání svázané s lidským jednáním, a to ve třech oblastech: v interakci s druhými lidmi, v interakci a zacházení s věcmi a v interakci s duchovními entitami. Pragmatici odmítají pasivní nahlížení podstaty věcí neboli čisté zření (theoría), odklánějící se od žité reality (HORVÁTH 2008: 36). Přitom pragmatický důraz na lidské jednání a aktivitu nemusí být chápán utilitárně a prakticistně. Pro Jamese je lidské jednání součástí jeho metafyzického náboženského konceptu: „svou vlastni činností můžeme působiti ke spáse světa, byt’ v sebemenším zlomku“. (JAMES in ČAPEK 2000: 55) Na sociální interakci zaměřený Mead pak tvrdí: „Základní projevy se zřejmě mění jen postupně a žádný jedinec nemůže přeorganizovat celou společnost; ale člověk svými postoji na společnost průběžně působí, protože zaznamenává postoj skupiny vi̊či sobě, reaguje na něj, a prostřednictvím této reakce mění postoj skupiny.“ (MEAD 2017: 112)

\section{Zkušenost}

S jednáním je svázán další, pro pragmatiky podstatný pojem. Tím je lidská zkušenost, u které Dewey zdůrazňuje její „imaginativní, energetický a zduchovnělý charakter“ (HROCH 2003: 35). Rovněž tímto pojetím zkušenosti se Dewey snaží vymanit z abstrahujícího karteziánského dualismu subjektu a objektu, jenž subjekt vyčleňuje z poznávacího a zkušenostního procesu. Oproti tomu Dewey postuluje vzájemnou interakci subjektu a objektu, jež vytváří dynamický celek.

13 Termín pragmatismus je odvozen od řeckého slova pragma, tj. věc. Ve svém významu tedy odkazuje nejen k praktickému životu, ale rovněž k věcnosti. Jako první používal termín pragmatismus americký filosof, logik a matematik Ch. S. Peirce, a to v letech 1871-1872 při setkáních v diskusním Metafyzickém klubu na Harvardově univerzitě. Metafyzický klub je dnes pokládán za prostředí, v němž se pragmatická filosofie postupně formovala. Pro označení specificky zaměřené filosofie použil termín pragmatismus veřejně poprvé W. James v roce 1898. 
Pragmatici akcentují zkušenost jako podmínku lidského poznání proto, že sama poznávaná skutečnost je „pluralistická, spontánně tvořivá, a proto nezachytitelná pouze rozumem“. (HROCH 2003: 15) Vycházejí z Jamesových výzkumů na poli psychologie. James ve své knize The Principles of Psychology tvrdí, že v poznávacím procesu vnímáme selektivně a aktivně zaměřujeme pozornost: „Milióny položek vnějšího řádu jsou vystaveny mým smyslům, které však nikdy nevstoupí do mé zkušenosti. Proč? Protože nejsou pro mne zajimavé. Pouze ty elementy, kterých si všímám, formují mou mysl - bez selektivního zájmu je zkušenost vnější chaos." (JAMES in HROCH 2003: 23; JAMES 1952: 187) Zároveň podle Jamese není lidská zkušenost omezena pouze na vědomě zakoušenou (a tedy pojmově uchopitelnou) realitu, ale máme zkušenost i s těmi entitami, pro něž nám chybí slovní vyjádření. Například pocitujeme vztahy nebo atmosféru situace, aniž bychom tuto zkušenost byli schopni verbalizovat.

James s Deweyem v návaznosti na tuto psychologickou zákonitost rozlišovali dvě úrovně lidské zkušenosti - primární vrstvu zkušenosti, která je běžná a bezprostřední, a sekundární zkušenost, která je reflexivní a zprostředkovaná. Přičemž sekundární zkušenost zpětně působí na zkušenost primární, jejím smyslem je reflektovat a vyjasňovat význam primární zkušenosti (VIŠŇOVSKÝ 2014: 45-46). Rozlišení dvou vrstev zkušenosti a rovněž dekomponování procesu vnímání a definování proudu vědomí (stream of consciousness) Jamesem v The Principles of Psychology umožnilo následně G. H. Meadovi rozpracovat jeho pojetí Self (Já), rozlišené na dva procesuální komponenty I a Me (JAMES 1952: 215).

Procesuální charakter zkušenosti vychází podle pragmatiků z toho, že sekundární zkušenost je vytvářena na základě předchozí bezprostřední zkušenosti, a zároveň zpětně na tuto zkušenost působí. Pragmatici si navíc uvědomují, že zkušenost může být ve vztahu k objektovému světu jak retrospektivní (vzpomínky na minulost a její znovunahlížení a přehodnocování), tak projektivní (HROCH 2003: 36). V projekci se zaměřujeme na budoucnost a na základě předchozí zkušenosti můžeme modifikovat své budoucí jednání nebo jeho zacílení. V The Principles of Psychology James definuje lidské vnímání dynamicky jako časovou událost. Př́tomný okamžik chápe jako strukturovaný celek, který zahrnuje vlastní prítomnost a nedávnou prítomnost ${ }^{14}$ (HROCH 2003: 22; JAMES 1952: 396-420). To umožňuje pragmatikům vymanit se ze statického chápání kognitivních procesů a akcentovat časový rozměr poznání, jednání a zkušenosti.

\section{Sociální interakce}

Na přelomu 19. a 20. století dochází v humanitních vědách k obrácení pozornosti k sociálním vztahům a soužití lidí a k oslabení individuálního chápání člověka. At̉ už je americký pragmatismus spolutvůrcem této změny orientace, nebo reaguje na duchovní proměnu moderní euroamerické společnosti, jisté je, že vzájemné jednání lidí se stává jeho dalším podstatným zájmem. V návaznosti na akcentování lidského jednání (action) rozvijejí pragmatici koncept interakce (interaction):

14 „Nedávná př́ítomnost je to, co ještě neuplynulo, avšak již něco ztratilo ze své svě̌̌esti a novosti.“ (HROCH 2003: 22-23) 
Klasický pragmatizmus obhajuje metafyzický interakcionismus ako koncepciu sveta, v ktorom všetky entity interagujú, či už priamo a vzájomne, alebo nepriamo a sprostredkovanie cez d’alšie entity a vztahy. V sociálnej filozofii a etike pragmatismu rozpracoval túto koncepciu George Herbert Mead (1934), no už pred ním písala v tomto duchu Jane Addams (1902), ktorá dokonca explicitne hovorila o ,princípe reciprocity ako o podstatnej súčasti morálky a spoločenských vztahov vôbec. (VIŠŇOVSKÝ 2014: 221) $)^{15}$

\section{Symbol, význam a pravda}

Pro porozumění filosofického zázemí symbolického interakcionismu je třeba se ještě věnovat koncepcím symbolu, významu (meaning) ${ }^{16}$ a pravdy v pojetí pragmatismu. V případě symbolu je nezbytné se vrátit k zakladatelskému dílu Ch. S. Peirce a jeho triadické koncepci znaku. Peircovo základní znakové schéma tvoří triáda representamen (resp. vehikulum), objekt a interpretans, ve kterém representamen zastupuje objekt vzhledem k interpretantu ${ }^{17}$ (PALEK 1997: 8-9). V Peircově triadickém schématu je interpretans produktem myšlení a označuje ideu, kterou znak v interpretovi vyvolal. Např́íklad kouř, zastupující vzdálený a neviděný oheň, vyvolá v interpretovi ideu požáru. Peirce rozlišuje významy (meaning) vnitřní a vnější a přiřazuje je $\mathrm{k}$ třem modelům znaků - ikona, index, symbol: „Pokud se znak nějak podobá objektu, čili je zde ikonická podobnost, pak tuto nazývá vnitřním významem neboli hloubkou výrazu. Indexové spojení s objektem vytváří vnější význam (external meaning), (např. písmena umístěna na diagramu ukazují přímo objekty). Symboly mají podle Peirce význam určován interpretantem." (PALEK 1997: 19-20) Peirce zároveň dospěl k názoru, že „interpretans symbolu musí nakonec spočívat ve zvyku, nikoliv v bezprostřední reakci na znakové vehikulum nebo v průvodních představách nebo emocích [...].“ (MORRIS 1997: 227) Interpretans je v případě symbolu chápán jako zvyk, případně konvence reagovat v důsledku znakového vehikula na nepřítomné objekty tak, jako by byly př́ítomné. Při objevení znakového vehikula očekává interpret určitou situaci a na základě tohoto očekávání se může částečně připravit na to, co může následovat (MORRIS 1997: 227-228).

Zatímco se Peirce ve svém pragmatismu zaměřil na logiku jako prostředek myšlení a vědeckého zkoumání, jeho žák James své pojetí pragmatismu rozšířil na jednání

15 Obdobný zájem o studium mezilidských vztahů můžeme sledovat v tomto období i v oblasti divadelní vědy. Ve třicátých letech 20. století, kdy na Chicagské univerzitě působí G. H. Mead, rozpracovává u nás svou teorii dramatického díla Otakar Zich. V Estetice dramatického uměni (1931) analogicky definuje dramatické postavy jako „lidi vespolek jednající“ (ZICH 1931: 47) a dramatický děj jako „vespolné jednání lidí“ (tamtéž). Dramatické dílo je pak „umělecké dílo, předvádějící vespolné jednání osob hrou herců na scéně“ (ZICH 1931: 68). Zmíněné citace zde nemají sloužit jako doklad vyspělosti české teatrologie. Spíše mají poukázat na užívaný pojmový aparát (vespolné jednání), který je analogií k anglickému termínu interaction.

16 Vzhledem k tomu, že pragmatici ruší tradiční dichotomii objekt-subjekt, nebot poznávaný objekt a poznávací subjekt jsou vzájemně propojeny, do češtiny se anglický pojem meaning nikdy nepřekládá jako smysl, ale jako význam.

17 V dyadickém pojetí znaku Ferdinanda de Saussera je znak psychickou jednotkou o dvou stránkách. Oba prvky znaku - označované (pojem, signifié) a označujici (akustický obraz, signifiant) - jsou spjaty a jeden podmiňuje druhý (SAUSSERE 1989). 
a zkoumá, jak se význam myšlení projevuje v jednání a změnách jednání. Původní Peircovo teoreticko-metodologické zaměření na výzkum a vědu James rozšíríl o otázky prakticko-etické a zkoumání smyslu myšlení pro jednání (VIŠŇOVSKÝ 2014: 27). Umožnil mu to samotný Peirce, který navázal na pojem „pragmatický“, Kantem definovaný jako to, co transcenduje myšlení směrem k praxi skrze jeho účinky (VIŠŇOVSKÝ 2014: 29). V pragmatické filosofii pak význam není pouze myšlenkovou aktivitou interpretujícího, ale je vázán na lidskou aktivitu vůbec, na jednání ve světě a s druhými. Význam se v jednání vyjevuje.

V této souvislosti je nutné se ještě zmínit o pojetí pravdy v pragmatismu. Pragmatici odmítali racionalistické pojetí pravdy, která se odehrává „v čistě logické nebo epistomologické dimenzi, odlišné od dimenze psychologické“ (JAMES 1918: 154). Pravdu chápou procesuálně, ve vztahu k lidské zkušenosti, a jakožto ověřovací procesy: „Pravda ideje není nehybnou, inherující vlastností. Pravda přichází k ideji. Idea se stává pravdivou, jest učiněna pravdivou fakty. Její pravdivost je vlastně událost, proces, tj. proces ověření, vlastní verifikace." (JAMES 1918: 134) Ačkoliv je pro Jamese pravda lidským výtvorem, netvrdí, že za pravdu můžeme vyhlásit libovolné přesvědčení podle jeho výhodnosti a užitečnosti. Pravdivost je podle Jamese určena vztahem mezi naším přesvědčením a fakty a tento vztah je verifikován v reálném jednání (VIŠŇOVSKÝ 2014: 36).

\section{Sociální psychologie G. H. Meada}

Klíčovou postavou symbolického interakcionismu je představitel filosofie pragmatismu a sociální psycholog George Herbert Mead. Působil na Chicagské univerzitě, kde přednášel od roku 1900. Jeho přednášky sociální psychologie, které se staly základem knihy Mind, Self, and Society (1934; česky Mysl, já a společnost, 2017) navštěvovali studenti různých humanitních oborů. Mead vyšel $\mathrm{z}$ amerického behaviorismu zaměřeného individuálně a rozšsiríil tento zájmem o společnost a chování a jednání člověka ve společnosti. Meada bytostně zajímá dynamičnost sociálního aktu, životní procesy sociální skupiny a to, jakým způsobem se tyto procesy projevují ve vnitřní zkušenosti jedince.

Shrnout na malé ploše této studie podstatné aspekty Meadovy sociální psychologie je nemožné. Proto se soustředíme jen na ty pojmy a koncepty, které sehrály významnou roli při formování symbolického interakcionismu. Jako první je třeba zmínit procesuální chápání sociálního aktu, situace, jednání, myšlenkových procesů a lidského já, které Mead přejímá od Jamese. Zahrnutí procesuality a časovosti umožňuje zmíněné fenomény dekomponovat a sledovat vztahy mezi jejich jednotlivými fázemi.

\section{Procesuálnost sociálního aktu}

U sociálního aktu Mead rozlišuje jeho vnitřní a vnější fázi. Vnitřní fáze je spjata s vnitřní zkušeností jedince, ve vnější fázi se tato zkušenost vyjevuje. Sociální akt nelze vysvětlit pouze na základě schématu podnětu-reakce. Je komplexním organickým procesem, zahrnujícím 
předchozí (sekundární) i právě nabývanou (primární) lidskou zkušenost, která je v podnětech i reakcích obsažena (MEAD 2017: 18). Chronologicky Mead sociální akt dekomponuje na počáteční, bezprostřední a pozděǰ̌i fázi, které v sobě pojímají postoje jednajících, např. v počáteční fázi je obsažena intence a připravenost k jednání. Mead uvádí příklad člověka, který chce pracovat $\mathrm{s}$ kladivem. $\mathrm{V}$ počáteční fázi tohoto aktu, kdy se ruka ke kladivu přibližuje, je ruka na svalové úrovni již připravena kladivo uchopit (MEAD 2017: 24).

Stejně procesuálně chápe Mead myšlenkové procesy člověka. Dynamický a časový charakter vnímání a myšlení si podle Meada uvědomuje každý člověk, nebot každý si uvědomuje časové pořadí myšlenkových pochodů, nebo např. schopnost uspořádat v časovém pořadí věci, které se chystáme dělat (MEAD 2017: 57). Např́íklad rozhodování při zahajování interakce s nadřízeným.

Pro jednání člověka je specifická „přítomnost alternativních možných dokončení jakéhokoli daného aktu“ (MEAD 2017: 57). Díky této reflektivní inteligenci vnímáme minulost a budoucnost, ale rovněž ve vztahu k jednání nám reflektivní inteligence dává možnost odložit reakci na podnět. Tato povýtce lidská schopnost nám umožňuje, abychom o svém jednání a chování rozhodovali, dává nám svobodu. Zároveň se z hlediska sociální psychologie odložená reakce vztahuje $\mathrm{k}$ vytvářenému významu sociálního dění a k postoji, který zahrnuje ideu: „Někdo vás ohrožuje a vy ho na místě srazíte k zemi. V takové situaci není obsažen žádný prvek ideje. Pokud počítáte do deseti a zvážíte, co tato hrozba znamená, máte ideu, měníte tuto situaci na uspořádání zahrnující ideu.“ (MEAD 2017: 113)

Reflektivní inteligence dává člověku možnost využít ve svém jednání minulou zkušenost (paměṫ). Rovněž ji využíváme při anticipování budoucnosti (projekci). V prŕípadě sociálního aktu je naše budoucí jednání ovlivňováno vedle osobní zkušenosti i významovými gesty druhých, na něž reagujeme a své jednání jim přizpůsobujeme. Zde bude třeba přejít $\mathrm{k}$ dalším konceptům Meadovy sociální psychologie. Jedná se o pojmy play (hraní) a game (hra) a pojem Self (Já), tvořené komponentami $I$ a $M e$.

\section{Play a game}

Koncept play a game (hraní a hra) umožňuje Meadovy rozlišit individuální jednání od jednání sociálního. ${ }^{18}$ Hrani (play) vztahuje Mead k hraní rolí dítěte, tzv. hrani na..., při němž existuje „prostá následnost jedné role za druhou“ (MEAD 2017: 88). Dítě si hraje na maminku, na doktora, na automobilového závodníka apod. Oproti tomu ve hře (game) musí dítě v sobě zahrnout i postoje ostatních spoluhráčů a protihráčů, jež účastník předpokládá a jež řídí jedincovu reakci. Mead uvádí jako př́ílad týmovou (kolektiv-

18 Z hlediska fenomenologie hry, jak ji rozpracovali Johan Huizinga v Homo Ludens. Proeve eener bepaling van het spel-element der cultuur (1938); česky Homo ludens: o piovodu kultury ve hře (1971) (druhé vydání 2000) a předně Eugen Fink v Oase des Glücks (1957); česky Oáza štěstí (1992) a v knize Spiel als Weltsymbol (1960); česky Hra jako symbol světa (1993), není Meadovo rozlišení na play a game zcela opodstatněné. Meadovi pomáhá odlišení individuálního hraní v play a skupinového hraní v game při definování sociálního jednání podle pravidel (game). Podle Huizingy a Finka jsou ale pravidla závazná pro všechny typy her a hraní, respektive v českém kontextu hraní si. 
ní) hru baseball, v níž hráč nepřejímá pouze postoje jednotlivých jedinců jako v případě hraní rolí, ale přejímá a zaujímá postoj organizované sociální skupiny. V tomto případě těch, kteří hrají stejnou hru: „Pokud má jedinec postoj člověka, který hází míček, může mít rovněž reakci chytání tohoto míčku. Obojí je ve vzájemném vztahu a slouží účelu samotné hry.“ (MEAD 2017: 88)

Takto chápaná hra je pro Meada ilustrací situace, v níž vzniká organizovaná osobnost. Jedincovo já na tomto stupni psychosociálního vývoje je schopno skládat postoje jednotlivých jedinců do organizovaných společenských nebo skupinových postojů a jednat podle nich (MEAD 2017: 88-89). Přŕkladem zde může být jedincovo vědomí mravních postojů určité skupiny, které jsou zahrnuty v postoji samotného jednice, Meadem nazvané zobecnělý druhý (generalized other). V tomto typu jednání si „interaktivně jednající osoba uvědomí význam svého gesta nikoli až díky reakci druhých, nýbrž je schopna vyvolat v sobě samé reakci, kterou chce vyvolat v druhých. Tento proces byl označen jako ,taking the role of the generalized other" "19 (PAUL 2005: 17)

\section{Self, I a Me}

Schopnost člověka přejímat postoje druhých a zakomponovat je do svého jednání definuje Mead pomocí konceptu Self (Já), který chápe jako sociální strukturu. Self má dva procesuální komponenty - I a $\mathrm{Me}^{20}$, jež se vzájemně ovlivňují. Sám výraz Self je „reflektivní a odkazuje na to, co může být subjektem i objektem“ (MEAD 2017: 68). Komponent I je subjektové já (má blízko k Jungově bytostnému já), je s ním spojena svoboda a iniciativa. Aby se člověk sám sobě stal objektem, aby se dostal vně sebe, musí vstoupit do zkušenostního pole s jinými jedinci, s nimiž jedná v sociální situaci. Jinými slovy musí zaujmout postoje jiných ve společné interakci. To mu umožňuje druhý komponent, Me - objektové a sociální já. Teprve na základě interakce mezi Me (např̀. sociální rolí, kterou člověk zaujal - žák/yně) a I, které vzniká tak, že reaguje na sociální a objektové Me, může vzniknout Self jako sociální struktura. Tím rovněž dochází k sebeuvědoměni si člověka, k vyjevení Já. Podle Meada tedy dochází k sebeuvědomění si člověka jakožto individuality až na základě vstupu do sociální interakce. Jinými slovy sociální jednání podmiňuje vznik Já jakožto subjektu. ${ }^{21}$

19 V roce 1970 se Meadovou sociální psychologií inspiroval západoněmecký teatrolog Arno Paul ve své habilitační přednášce Divadelni věda jako nauka o divadelním jednáni. (Německý překlad Meadovy knihy Mind, Self, and Society vyšel v roce 1968.)

20 Někteří autoři tyto výrazy nepřekládají do češtiny a nechávají je v původním anglickém tvaru. Stejným způsobem postupujeme v tomto textu i my, nicméně se můžeme v odborné literatuře setkat také $\mathrm{s}$ českým ekvivalentem JÁ pro I a Mne pro Me (viz např. KAREL 2010).

21 Zajímavé je domýšlet vznik já u člověka a sebeuvědomění si sebe sama z hlediska dětské vývojové psychologie (viz Jean Piaget). Vyjevení subjektového já, okamžik, kdy se dítě přestává pojmenovávat ve třetí osobě a přechází do osoby první, kladou dětští psychologové do věku zhruba tř́ let. Rozvoj reflektivních myšlenkových operací pak vývojově kladou do věku zhruba dvanácti let. 


\section{Významové gesto a významový symbol}

Schopnost člověka přejímat do svého chování a jednání postoje druhých osob je v Meadově sociální psychologii osvětlena koncepty vokálni gesto, významové gesto a významový symbol. Mead v návaznosti na studium gest u experimentálního psychologa Wilhelma Wundta na lipské univerzitě22 definuje gesto jako samostatný projev, který „není pouhou ilustrací řeči. Gesta ,hovoří sama a předcházejí řeči. Jsou součástí sociálního chování a umožňují nám číst emocionální postoje a ,významy chování jiných lidí, když si toho třeba ani nejsou vědomi“.“ (MEAD 2017: 27) Zároveň se nevědomě „klademe na místo druhých a chováme se, jako se chovají druzí“. (MEAD 2017: 44)

Na podobném principu definuje Mead pojem vokální gesto: „Význam vokálního podnětu pak spočívá ve faktu, že jedinec slyší, co říká, má sklon reagovat, jako reaguje druhá osoba.“ (MEAD 2017: 44) Chování a gesto, které v nás vyvolává reakci, jakou vyvolává v druhém člověku, nazývá Mead vokálními gesty neboli symboly. Na jejich základě je člověk schopen proměňovat své vlastní pozdější chování. Tím se ale tento proces stává společnou reakcí, která ustanovuje sociální chování i význam objektu. Např́íklad pokud člověk unáhleně okřikne svého zaměstnance a je schopen zaujmout jeho postoj, jakožto postoj nespravedlivě okřiknutého, může tomuto postoji své jednání následně (případně v průběhu) přizpůsobit. Vztah mezi gestem a přizpůsobením pozdějšího chování vytváří pole, v němž vzniká význam. Tak je význam spojen se sociálním procesem a nachází se výhradně v poli zkušenosti (MEAD 2017: 50-51).

Na divadelní charakter významového symbolu a zobecnělého druhého v nás upozornil německý teatrolog Arno Paul:

Tento vztah k sobě samému v sociálním jednání, který je nutno označit již za divadelní prvek, předpokládá vlastní identitu, jež se vyvíjí tak, že člověk přejímá do obrazu o sobě samém také způsoby chování jiných. [...] Pokud se člověk umí přenést do role druhého, může se pak z této pozice do jisté míry podívat i na sebe sama a stává se sobě objektem. Interakčnímu subjektu se tak daří předvídat reakce, které by jeho jednání mělo vyvolat u druhých. (PAUL 2005: 17)

Tuto schopnost pohližet na sebe očima druhých definoval jiný představitel filozofického pragmatismu Charles Horton Cooley ve známém konceptu zrcadlového já (looking-glass self) (COOLEY 1902).

22 Otázkou zůstává, zda Meada rovněž neovlivnilo pojetí gesta F. Delsarta, respektive americký delsartismus. Je známo, že Ch. S. Peirce byl díky své druhé manželce (herečce) v kontaktu s J. Steele Mackayem, žákem F. Delsarta a propagátorem jeho systému herecké pedagogiky v USA. Delsartovo triadické pojetí expresivity gesta mělo vliv na vznik Peircova triadického modelu znaku (SMITH FISCHER 2013: 371-394).

23 Tato lidská schopnost vychází z nápodoby, jejíž procesy se spouštějí okamžitě po narození člověka. V poslední době řadu těchto operací vysvětlili vědci na základě objevu tzv. zrcadlových neuronů týmem prof. Giacoma Rizzolattiho v roce 1996. Podobný princip nalezneme ale již v díle sv. Augustina De Magistero. Podle Augustina, abychom se mohli učit, musíme mít v sobě učitele. Slovy Meada musíme zaujmout postoj učitele. 


\section{Symbolický interakcionismus}

Pragmatismus, z něj vycházející sociální psychologie G. H. Meada a následné chicagské městské studie (urban studies) daly vzniknout specifické teorii symbolického interakcionismu. ${ }^{24}$ Přestože tento termín vnesl do sociální teorie americký sociolog Herbert Blumer až v roce 1937, bývají za rané interakcionisty označováni i myslitelé žijící a působící o řadu let dříve, o nichž již byla řeč v předchozím textu, jako např́ílad J. Dewey, Ch. H. Cooley a především G. H. Mead. Do tohoto výčtu je možné započítat také významného představitele Chicagské školy W. I. Thomase a jeho definici situace, o které se zmíníme v následující části.

Snahou raných interakcionistů bylo především rozpracovat východiska sociologické a sociálně psychologické teorie, která ve své době stála v opozici k dominantnímu pozitivismu. Dnešní pojetí symbolického interakcionismu vychází zejména z textů Herberta Blumera $^{25}$ z 50. a 60. let minulého století. ${ }^{26}$

H. Blumer ve své knize Symbolic Interactionism: Perspective and Method (1969), v níž definoval základní principy symbolického interakcionismu, uvádí tři klíčové premisy (BLUMER 1969: 2). První premisou je, že „lidé jednají s věcmi na základě významů, jaký pro ně tyto věci mají.“ Podle druhé Blumerovi premisy je „význam takovýchto věcí odvozen nebo vyvstává ze sociální interakce, které se jedinec účastní spolu s ostatními.“ A konečně podle třetí premisy jsou „tyto významy obsaženy a modifikovány v interpretativním procesu, který jedinec používá při zacházení s věcmi, jež potkává.“

Základní premisy, které Blumer ve své knize postupně rozvádí, jsou zásadní pro pochopení východisek tohoto sociologického směru. Do velké míry se jedná o fenomény rozpracované pragmatisty a G. H. Meadem, o nichž pojednávaly předchozí kapitoly. Blumer a další symboličtí interakcionisté z těchto definic vycházejí, zpřesňují jejich významy z hlediska sociologie a uspořádávají je do funkční a víceméně celistvé teorie. V následující části nám půjde právě o vysvětlení základních postulátů pokročilého symbolického interakcionismu. Pokusíme se je osvětlit a aplikovat na př́kladu politické kulturní performance, které jsme se účastnili v rámci semináře Teatralita veřejných událostí na Katedře divadelních studií FF MU dne 25. září 2013. ${ }^{27}$ Nejprve

24 Sociální interakcí se zabývala a zabývá celá řada dalších teoretických konceptů, za symbolický interakcionismus se ale označují pouze ty koncepce, které vycházejí z myšlenek G. H. Meada.

25 Blumer studoval na Chicagské univerzitě, kde absolvoval v roce 1925. Byl žákem G. H. Meada, který měl zásadní vliv na jeho práci.

26 Symbolický interakcionismus neexistuje jako kompaktní směr. Vedle uvedené nejvlivnější Chicagské školy, definované Herbertem Blumerem, existuje ještě tzv. Iowská škola Manforda Kuhna, profesora Iowské univerzity, která se liší především v metodologickém př́stupu. Kuhn se oproti Blumerovi pokoušel dokázat Meadovu teorii pomocí empirického výzkumu. Rovněž se lišili „, př́ístupu ke struktuře subjektu a determinaci jeho chování, jakož i v Blumerově zdůraznění procesuální stránky a Kuhnově důrazu na strukturu.“ (PODHOROVÁ 1980: 53) Mezi interakcionisty bývají řazeny také školy a přístupy vycházející z amerického pragmatismu, G. H. Meada i Chicagské školy jako etnometodologie Harolda Garfinkela či dramaturgický př́stup Ervinga Goffmana. Na tyto směry v soudobé sociologii částečně navazují teoretici jednání jako James Coleman, Randall Collins a Anthony Giddens.

27 Materiály $\mathrm{k}$ tomuto př́kladu jsme shromaždovali metodou zúčastněného pozorování, při kterém jsme také pořídili řadu fotografických a audiovizuálních dokumentů, zároveň jsme sbírali mediální výstupy vázající 
stručně popíšeme průběh uvedené události, abychom se následně mohli věnovat jejím jednotlivým aspektům z pohledu teorie symbolického interakcionismu.

V čase předvolební kampaně do dolní komory Parlamentu ČR v roce 2013 vystoupilo v Brně v jeden den na různých místech několik čelních představitelů nejvýznamnějších politických stran. V jeden moment probíhala diskuze předsedy ČSSD Bohuslava Sobotky a představitele ODS Petra Fialy v konferenčním sále Divadla Husa na provázku. Ve stejný moment $\mathrm{v}$ jiné části tohoto divadla vystoupil neúspěšný kandidát $\mathrm{z}$ předešlé volby prezidenta a předseda strany TOP 09 Karel Schwarzenberg u př́ležitosti 45 . výročí založení divadla. Kromě toho ale proběhlo také setkání občanů s čerstvě zvoleným prezidentem ČR Milošem Zemanem na brněnském Náměstí Svobody. Pro náš účel je vhodná zvláště událost vystoupení prezidenta Zemana, nebot v ní docházelo k signifikantnímu vyjednávání symbolických významů.

Kulturní performance setkání prezidenta Miloše Zemana s občany proběhla ve stř̌edu 25. zárí 2013 na brněnském Náměstí Svobody krátce po 16. hodině. Prezident ve stanoveném čase přijel na náměstí v koloně prezidentských vozidel ozdobených českými státními symboly, kde na něj čekal dav přibližně čtyř až sedmi set lidí. Na připraveném podiu umístěném ve východní části náměstí uvítal prezidenta Miloše Zemana hejtman Jihomoravského kraje Michal Hašek spolu s primátorem města Brna Romanem Onderkou.$^{28}$ Již v momentě, kdy se aktéŕri ${ }^{29}$ na podiu vítali, tedy cca po dvou minutách od začátku Zemanova vystoupení, začal muž (cyklista s kolem) stojící v obecenstvu pískat na píštalku s jasným záměrem narušovat projev prezidenta Zemana. Miloš Zeman na pískání reagoval historkou o japonských vojácích v Tichomoří, kteří se po ukončení druhé světové války domnívali, že boje stále probíhají. Část účastníků kulturní performance reagovala na prezidentova slova smíchem.

Zhruba ve třetí minutě svého projevu Zeman explicitně definoval důvod své návštěvy, v níž se mělo jednat o naplňování funkce prezidenta C̆R. Miloš Zeman prohlásil, že jako přímo zvolený prezident má povinnost skládat účty svým voličům. Během tohoto proslovu nespokojený účastník ovšem vytrvale pokračoval v pískání a donutil Miloše Zemana $\mathrm{k}$ další reakci. Zeman vyzval spoluaktéra $\mathrm{k}$ vyjádření své nespokojenosti v parlamentních volbách. Zatímco prezident pokračoval ve svém proslovu, který byl ovšem tematicky věnován politice stranické a vládní, nikoliv prezidentské, se kolem pískajícího muže vytvořil kruh Zemanových př́inivců, kteří ho slovně napadali. Po sedmi minutách od začátku prezidentova vystoupení byl pískající aktér násilně odveden městskou policií z mítinku. Minutu na to ukončil svůj projev prezident republiky a dal prostor pro dotazy, přičemž vyzval pískajícího muže k tomu, aby položil první otázku, ten ale byl již v rukou městské policie. Následující dva dotazy z publika tematizovaly právě probíhající

se k této události. Veškeré materiály, včetně protokolu z terénního výzkumu, jsou uloženy v archivu Katedry divadelních studií FF MU. Je nutné ale dodat, že v následujícím textu nám půjde především o demonstraci teoretického aparátu symbolického interakcionismus. Nejedná se tedy o plnohodnotnou př́padovou studii, jakkoli zachováme při popisu události věcnou správnost.

28 Podium stálo vedle kovové kašny a bylo situované směrem $\mathrm{k}$ časostroji stojícímu v jižní části náměstí. Díky tomu, že náměstí v tomto směru mírně stoupá, vznikla nepatrná elevace hlediššě.

29 V tomto textu používáme označení „aktér“ pro všechny jednající účastníky interakce. 
volební kampaň do parlamentu ČR. Po přibližně 15 minutách celá kulturní performance skončila a prezident, hejtman i primátor opustili brněnské náměstí.

\section{Objekt a význam}

Na příkladu této stručně popsané kulturní performance se pokusíme demonstrovat základní premisy symbolického interakcionismu. Nejprve je nutné představit definici objektu, na jehož základě následně můžeme pochopit, jak symbolický interakcionismus chápe symbol. Objektem Blumer chápe „cokoliv, co může být označeno, cokoliv, k čemu je odkazováno, nebo co je s něčím spojováno." (BLUMER in HORVÁTH 2008: 47) Předmět se stává objektem v momentě, když se k němu aktér chová, působí na něj či ho označuje. Objekt je zároveň určen účelem, či cílem jednání. Samotný mítink s prezidentem je objektem, protože ho účastníci mohou nějak označit (například jako „setkání s prezidentem“) a určitým způsobem se k němu vztahují (může pro ně být úctyhodnou tradicí, př́ležitostí vidět prezidenta na vlastní oči atp.). Stejně tak se objektem stává samotný prezident, nebot vůči němu účastníci mítinku aktivně jednají, otáčí se k němu, poslouchají jeho projev nebo mu tleskají. $\mathrm{V}$ okamžiku, kdy někteří účastníci mítinku upírají pozornost k pískajícímu aktérovi, přestávají jednat vůči prezidentovi, v tomto momentě pro ně osoba prezidenta ztrácí sociální signifikanci a přestává být objektem.

Existence objektu je tedy neoddělitelná od jednání aktéra. ${ }^{30}$ Znalost o předmětech vnějšího světa jedinec získává výhradně prostřednictvím toho, jak na něj tyto předměty působí a jak vůči nim jedná. Jinými slovy můžeme říci, že prostředí je plné předmětů, ale objektů je jen tolik, kolik jich jedinec v daný moment vnímá (PODHOROVÁ 1980: 41). Signifikantním se takový předmět stává v momentě, kdy je označen jako objekt prostřednictvím symbolu ${ }^{31}$ (PODHOROVÁ 1980: 41). Stejně tak konkrétního člověka jako takového nemohou lidé nikdy poznat, znalost o jeho osobě získávají pouze prostř̌ednictvím toho, jak na ně působí, či jak vůči němu jednají. Ještě patrnější je to na abstraktnějších objektech, jako je například funkce primátora, která je určena tím, že je konkrétní člověk zvolen do této funkce a jedná či je vůči němu jednáno tak, aby to odpovídalo významu této funkce (např́klad je oslovován „pane primátore“ nebo při zasedání městského zastupitelstva sedí na exponovaném místě).

Podle symbolických interakcionistů je každý objekt určen významem, který má pro jednajícího. Zároveň jeden objekt může mít mnoho významů pro různé jedince. „Význam objektu pro jedince vyvstává v zásadě ze způsobu, jakým ho definují ti, se kterými interaguje." (BLUMER 1969: 11) Tento význam je ovšem proměnlivý, vyvstává z předešlé

30 Jednáním zde může být i záměrné obrácení pozornosti k jinému aktérovi. Za jednání tedy můžeme považovat např́klad situaci, kdy účastníci mítinku přestanou vnímat Michala Haška s Romanem Onderkou a svou pozornost zaměří na interakci mezi Milošem Zemanem a pískajícím mužem.

31 Zde je patrná inspirace pragmatickou definicí symbolu, podle které je význam symbolu určován interpretantem. 
zkušenosti aktéra a může být neustále přizpůsobován interakční situaci. ${ }^{32}$ Přítomnost Michala Haška a Romana Onderky tak může mít pro různé jedince v různých fázích interakce různý význam, nebot je možné je označit různými symboly. Michal Hašek může mít v jedné situaci význam přítele Miloše Zemana, v jiné význam hejtmana kraje a v další význam vnitrostranického odpůrce svého stranického předsedy Bohuslava Sobotky.

\section{Interakce a interpretace}

Jak bylo řečeno, objekt a jeho význam je spjat s aktérovým jednáním. Díky tomu má uvědomování si objektů a jejich významů procesuální charakter, probíhá v interakci s druhými subjekty. Blumer přiznává interakci zásadní význam, nebot’ se v jeho pojetí jedná o proces, který lidské jednání přímo formuje. Taková interakce není pouhým prostředkem nebo prostředím pro uvolnění lidského chování (BLUMER 1969: 8). Blumer a ostatní interakcionisté zdůrazňují svobodu aktéra v interakci, jež není předem determinována vnějšími ani vnitřními okolnostmi.

V interakci jedná aktér na základě významů, které objektům přisuzuje. Tyto významy se ale v průběhu interakce mohou modifikovat. Ostatně pragmatické pojetí symbolu, tak jak jsme o něm mluvili v předešlé kapitole, interpretaci jednajícího předpokládá, nebot jestliže je sociální interakce zprostředkována prostřednictvím symbolo̊, pak jak píše Blumer, toto „zprostředkování je ekvivalentní vsunutí procesu interpretace mezi podnět a reakci v př́ípadě lidského jednání." (BLUMER in KARGER 2010: 17)33

Podle Blumera probíhá interpretace ve dvou fázích. V první fázi si jednající stanovuje objekty, vưči kterým jedná a z nich si vybírá ty, jež jsou pro něho důležité. V tomto procesu dochází k interagování jedince sama se sebou - aktér komunikuje sám se sebou, a na základě toho potom může v druhé fázi interpretace manipulovat s významy ${ }^{34}$ (BLUMER 1969: 5).

Aktér během jednání nereaguje pouze na faktory, nýbrž své jednání konstruuje a řídí. Nejedná se o mechanické chování, ale o formativní proces, přičemž zásadní roli v interpretačním procesu hrají významy, které vyvstávají ve fázi „vnitřní interakce“, tedy při komunikaci aktéra sama se sebou (BLUMER 1969). Tento proces můžeme demonstrovat na procesu vnitřní interakce výzkumníka (jednoho z autorů této studie), který se rozhoduje, na jaké aspekty interakce mezi prezidentem a pískajícím mužem se zaměří a jak bude reagovat. Například bude-li výzkum provádět mezi publikem v blízkosti muže s píštalkou, jehož jiní účastníci v průběhu interakce slovně napadají a vypouští duši u kola, nebo v těsné blízkosti pódia, kde bude sledovat jednání prezidenta Zemana

32 Blumer v tomto pojetí vychází z pragmatické tradice a Meadovy teorie významu. Z takového pojetí také vyplývá, že neexistuje nic jako objektivní svět, resp. objektivní je to, co za objektivní označíme, co za objekty považujeme. Jinými slovy objekty, které nás obklopují, jsou sociální konstrukcí.

33 Zde je patrná inspirace G. H. Meadem, jeho procesuálním chápáním sociálního aktu a schopnosti člověka „odložit reakci“. (viz kapitola Procesuálnost sociálního aktu)

34 Blumer a další sociologové v této souvislosti používají pojem manipulace, jenž má v češtině negativní konotace. V tomto pojetí se ale jedná o neutrální označení. 
a jeho sympatizantů, nebo jestli zaujme stanovisko nezúčastněného pozorovatele a bude pouze zpovzdálí celou situaci dokumentovat. Výzkumník coby aktér v této fázi interpretuje jednání Zemanových stoupenců jako méně závažné, nebot nedochází k fyzickému napadání. Na základě toho potom připisuje význam, tedy že jde o nenásilný názorový střet. Díky takto ustanovenému významu v následujícím čase může zvolit způsob, jakým bude jednat. Rozhoduje se do střetu nezasahovat a uchovat si pozici nezúčastněného pozorovatele, kterou shledává vzhledem k pozici výzkumníka jako vhodnější. Samotnému jednání aktéra v interakci se budeme šířeji věnovat v následující části.

Schopnost interpretovat a definovat význam objektů, se kterými jedinec interaguje, podmiňuje existenci a průběh interakce. Díky této schopnosti připisují symboličtí interakcionisté jedinci schopnost svobodného rozhodování a jednání v interakci. Bez této lidské schopnosti by ostatně ani nebylo možné jednat. Blumer doslova tvrdí: „Povaha objektu - jakéhokoliv a všech objektů - se skládá z významu, jaký má pro osobu, pro kterou je objektem. Tento význam určuje způsob, jakým objekt osoba nahlíží, způsob, jakým je připravena vůči němu jednat a způsob, jakým je připravena o něm mluvit.“ (BLUMER 1969: 11) Blumer zde navazuje na tzv. definici situace $\mathrm{W}$. Thomase, kterou formuloval ve známém teorému: „Jestliže lidé definují situace jako reálné, pak jsou reálné i ve svých důsledcích." (THOMAS 1928: 572) Jinými slovy lidé jednají podle toho, jak vnímají a reflektují konkrétní situaci, jak si ji definují a interpretují. ${ }^{35}$

Jednání všech účastníků v námi sledované události bylo formováno jednotlivými interakcemi, v nichž se momentálně nacházeli. Všichni aktéři jednali na základě toho, jaké významy objektům připisovali a jak interpretovali situaci, přičemž interpretace vycházela do určité míry z předešlé zkušenosti zúčastněných. Tuto zkušenost symboličtí interakcionisté nazývají sekundární úrovní zkušenosti. Lze předpokládat, že většina účastníků zkoumané události měla at̉ už přímou, nebo zprostředkovanou sekundární zkušenost s takovýmto či obdobným typem kulturní performance. ${ }^{36} \mathrm{~V}$ procesu interpretace mohla na základě vlastní zkušenosti přiřazovat objektům význam.

Situace vystoupení prezidenta v krajském městě by v případě, že by současně neprobíhaly parlamentní volby, byla interpretována jako úctyhodná tradice, spojená s tradiční symbolikou, která je s úřadem prezidenta spojována. Organizátoři dodrželi strukturu odpovídající dané události, u níž můžeme předpokládat kromě přítomnosti samotného prezidenta rovněž př́tomnost statutárních zástupců územního celku, tedy hejtmana kraje a primátora města. Miloš Zeman přijel v prezidentské limuzíně ve stanovený čas, vystoupil před občany města, pronesl osmiminutový proslov ${ }^{37}$ odpověděl na dva dotazy účastníků setkání, připnul trikoloru na vlajku města a ve stanovený čas náměstí

35 Thomas touto definicí v podstatě předurčil následující vývoj jedné $\mathrm{z}$ vlivných větví interpretativní sociologie a především teoretický př́stup symbolického interakcionismu.

36 Tuto kulturní performanci lze interpretovat jako tzv. ,jízdu králů“, při které hlava státu objiždí obce a setkává se s občany. V českém kontextu navazoval prezident Miloš Zeman na tradici masarykovských výjezdů do krajů. Pro účastníky kulturní performance z roku 2013 mohla být sekundární zkušenost také spoluutvářena bud' skrze přímou zkušenost $\mathrm{z}$ účasti na podobných mítincích předešlých prezidentů Václava Havla nebo Václava Klause, nebo případně zprostředkovaně ze sdělovacích prostředků či z vyprávění.

37 Proslov má v rámci této události zvláště důležitou úlohu, nebot vnáší konkrétní významy, s nimiž může řečník manipulovat a významně se podílet na tom, jak ostatní účastníci danou kulturní performanci definují. 
opustil. Všichni aktéři na podiu byli oblečeni ve formálním obleku, rozestavění aktérů na podiu, s prezidentem uprostřed, rovněž odpovídalo této př́ležitosti. Interpretace by $\mathrm{v}$ takovém případě mohla být pro účastníky setkání poměrně jednoznačná.

Její jednoznačnost narušil ale svým jednáním jeden z divákủ, který reagoval na Zemanovu přítomnost vytrvalým pískáním na píštalku. I když není možné s určitostí říci, jaká byla motivace pískajícího aktéra, mohli účastníci interakce interpretovat jeho jednání jako doznívání prezidentských voleb z ledna 2013. K tomuto závěru docházíme z několika důvodů. Jednak aktér začal pískat ihned, jakmile prezident vystoupil na podium, tedy ještě před tím, než promluvil. Na základě toho můžeme jeho jednání interpretovat jako nesouhlas s prezidentem samotným a s tím, co zosobňuje, nikoli pouze s obsahem jeho proslovu. Vzhledem ke kontextu se nabízí varianta, že si pískající aktér definuje objekt Miloše Zemana jako symbol vítěze prezidentské volby, s jejímž výsledkem nesouhlasí. Tento způsob interpretace se ostatně pokoušel nastolit samotný Miloš Zeman během svého projevu. V něm se pokoušel zacházet s významy tak, aby ostatní účastníci interpretovali muže s piśśalkou jako člověka žijící mimo realitu. V této manipulaci volil konkrétně následující slova: „chtěl bych tomu pánovi říci, že prezidentské volby skončily “" ${ }^{38}$ Následně spoluaktéra přirovnal k japonským vojákům v Tichomoří, kteří nezaregistrovali konec druhé světové války. Volba slov není náhodná a můžeme ji interpretovat jako snahu dehonestovat soupeře, označit ho za jedince, který si neuvědomuje politickou realitu v dané chvíli, což dokresluje Zemanova věta „a až ho někdo vysvobodí z džungle, přeju mu vše nejlepší.“

Pískající aktér volí pro jednání takové prostředky, které mu umožní co nejúčinněji vyjádřit svůj postoj. Na základě jeho jednání můžeme situaci definovat poměrně jednoznačně jako projev kategorického nesouhlasu občana ČR s př́tomností nové hlavy státu. Zeman naopak svým jednáním manipuluje s významy tak, aby byla situace definována jako vystoupení zmateného či zpozdilého člověka a zároveň, aby předvedl svou schopnost slovně ovládnout situaci.

Všechna gesta a symbolická interakce jsou součástí širšího kontextu a jednání, které může být mnohovýznamové. Tato mnohovýznamovost ale může vést ke kolapsu komunikace. Každá komunikace selhává v momentě, kdy se jedinci v rámci interakce neshodnou na stejném významu gest a symbolů. Aktér v komunikaci si nikdy nemůže být úplně jist tím, jakou reakci v př́ijemci gesta vyvolá, nicméně ji může předvídat, pokud se vžije do role př́jemce, jenž má gesto interpretovat. ${ }^{39} \mathrm{~V}$ úspěšné komunikaci přijímá aktér úlohu druhého a je schopný situaci interpretovat, pochopit motivace a názory druhých, vzájemně si definovat situaci.

Můžeme říci, že v námi sledované interakci k určitému kolapsu komunikace došlo. Přestože byla akce anoncovaná jako nekonfliktní ,jízda králư“, jednáním v interakci došlo ke změně tohoto významu. Na podiu přítomní R. Onderka a M. Hašek by za normálních okolností symbolizovali představitele správních celků, a tak by je i účastníci interakce mohli interpretovat. Ve stejném čase ale obě osoby zároveň reprezentovaly

38 Audionahrávka uložena v archivu Katedry divadelních studií FF MU.

39 Jedná se o proces popsaný G. H. Meadem v konceptu zobecnělého druhého, resp. Ch. H. Cooleyem v konceptu tzv. zrcadlového já (viz kapitola Play a game a Self, I a Me). 
jednu z politických stran, účastnící se předvolební kampaně, vnitrostranickou opozici vůči předsedovi této strany Bohuslavu Sobotkovi a rovněž názorové stoupence prezidenta Zemana. Všichni tři aktéři navíc na podiu používali neformální formu oslovení (tzv. tykání), což vnáší do interakce další symbolické významy. Použití neformální oslovení je v daném kontextu možné interpretovat jako vyjádření důvěrného vztahu.

Celou situaci také umocňoval fakt, že se předseda ČSSD Sobotka ve stejnou chvíli nacházel na politické debatě v nedalekém divadle, kde se v předvolební debatě utkal $\mathrm{s}$ předsedou ODS, Petrem Fialou. ${ }^{40}$ Symbolické významy této interakce byly proměňovány rovněž vysokou a aktivní účastí stoupenců Strany práv občanů ZEMANOVCI, konkurenční strany ČSSD, která veřejně podporovala Miloše Zemana. Na navršení symbolů se podílela taky přítomnost dobrovolníků účastnících se předvolební kampaně a rozdávající propagační materiály hnutí ANO 2011. ${ }^{41}$

\section{Nesymbolická interakce}

$\mathrm{V}$ předešlé pasáži jsme popsali, jak vnímají interakcionisté symbolické jednání, tedy to, kdy má aktér možnost kreativního přístupu, interpretace a manipulace s významy. Ne všechny lidské interakce ale nabízejí jedinci takové možnosti. Mead proto rozlišoval mezi symbolickou a nesymbolickou interakcí. Nesymbolická interakce je jednoduchá, automatická reakce, kdy jedinec reaguje na okolní svět, aniž by jednání okolních objektů interpretoval a připisoval jim další významy a vědomě kontroloval průběh tohoto zautomatizovaného chování. Může jít např́íklad o reakci na přírodní jev jako úskok před padajícím stromem nebo reakci na jiného jedince, jako třeba automatická odpověd' na pozdrav.

Nesymbolickou interakcí v námi popisované kulturní performanci mohlo být např́iklad vyděšení, když začal muž pískat. V momentě, kdy ale opadla prvotní emocionální reakce a jednající má čas vkládat mezi předmět a objekt interpretaci, stává se interakce symbolickou. Po prvotním šoku aktér interpretuje jednání muže jako odpor vůči Zemanovi, připisuje význam a definuje situaci a následně jedná např́ílad tím, že muži vypustí duši u kola.

40 Tato skutečnost nemusela být všem aktérům interakce známa, nicméně mohla mít pro jejich část určitý význam v interpretačním procesu.

41 Pokud je pro úspěch interakce podstatné sdílení významů jednotlivých objektů, potažmo shodná definice situace, tak tato mnohapolnost mohla způsobit kolaps komunikace. Je samozřejmě otázka, jak ostatní účastníci interakce jednání aktérů interpretovali a zda ke kolapsu komunikace skutečně došlo. Není naší ambicí se v tomto př́ípadě dobrat definitivního závěru. Zvláště z důvodu absence výpovědí přímých účastníků, což je dáno především tím, že původní zájem terénního výzkumu byl soustředěn na vizuální složku kulturní performance. Jednotlivé interakce, které se uskutečnily v rámci této kulturní performance, měly spíše posloužit za prríklad signifikantní manipulace s významy. Zároveň jsme chtěli ukázat, na základě jakých intencí mohou aktéři definovat situaci. 


\section{Zhodnocení a důsledky pro základní metodologii výzkumu}

Teoretický fundament symbolického interakcionismu logicky vedl také k definování vlastního metodologického přístupu. Vzhledem k tomu, že interakcionisté, podle pragmatické tradice, vnímají jedince jako svobodného aktivního činitele s jedinečnou pozicí ve struktuře společnosti, je jejich hlavní zájem soustředěn na každodenní interakci. Z toho vyplývá i metodologické hledisko výzkumu, které klade důraz na empirii výzkumníka. Každý badatel je součástí svého světa, kterému rozumí, a tak existuje riziko, že tyto zkušenosti bude přenášet do svého výzkumu. Proto Blumer rozděloval bádání do dvou fází: fáze explorace, ve které badatel získává znalosti o zkoumaném sociálním světě, tak aby mohl lépe pochopit problematiku zkoumaného objektu. V našem případě se jednalo o zúčastněné pozorování kulturní performance - mítinku s prezidentem, a pořízení audiovizuálních materiálů, sběr dostupných mediálních výstupů, shromažd'ování informací o teatralitě brněnských ulic ${ }^{42}$. Ve druhé fázi, nazývané inspekce, dochází k hodnocení empirického obsahu, analýze a zobecnění.

\section{Závěr}

Na základě příkladu uvedeného v předešlé kapitole jsme chtěli demonstrovat procesuální charakter symbolické interakce i fakt, že není pouze prostředkem pro vyjádření nebo uvolnění lidského chování, ale je procesem, který lidské chování formuje. Důraz na procesualitu a dynamiku symbolické interakce je důvod, proč shledáváme symbolický interakcionismus jako vhodné východisko pro další výzkum teatrality.

Cílem této studie bylo představit jeho základní premisy, teoretické ukotvení a ukázat, jaké přináší možnosti při analýze kulturních performancí. Symbolický interakcionismus vznikl v reakci na v té době vlivné sociologické směry, jako byl pozitivistický determinismus, evolucionismus a behaviorismus, které přestávaly mít schopnost vysvětlit sociální dění v rychle se modernizující společnosti. Ve stejné době, kdy vznikal symbolický interakcionismus, se rozvíjely i další podobně orientované sociálně vědní přístupy, jako je fenomenologická sociologie Alfreda Schutze, či sociologie vědění Karla Mannheima. Tyto př́ístupy, někdy označované za interpretativismus a interakcionismus, pracují se společnými pojmy: interpretace, jednání, interakce, vědění, význam a jazyk.

Symbolický interakcionismus ovlivnil celou řadu metodologických přístupů nejen v sociologii. Největší vliv měl logicky na ty oblasti sociálně-vědních oborů, které pracují se symbolickou povahou empirie. ${ }^{43}$ Kromě toho ale promluvil také do oblasti uměno-

42 Tento výzkum metodou zúčastněného pozorování probíhal v průběhu několika let.

43 Východiska symbolického interakcionismu, tak jak jsme je představili v předešlém textu, nacházíme už ve zmiňovaném díle Ervinga Goffmana. Z tradice symbolického interakcionismu částečně také vychází sociální konstruktivismus definovaný ve vlivné knize amerických sociologů P. L. Bergera a T. Luckmana Sociálni konstrukce reality (The Social Construction of the Reality 1966; česky 1999). Kvůli nástupu postmoderního myšlení na začátku 70. let dochází k určitému upozadění vlivu myšlenek symbolického interakcionismu. V po- 
vědných oborů, právě pro svoji schopnost vysvětlit symbolickou a procesuální povahu jednání.

Motivací k napsání této studie byla potřeba navrátit se k fundamentálním základům studia divadla a teatrality a osvětlit jedno z možných východisek tohoto bádání. Jak se ukazuje, filozofický pragmatismus, Chicagská škola, sociální psychologie G. H. Meada a z něj vycházející symbolický interakcionismus, umožňují ono široké rozkročení napříč různými vědními obory. Ukazují ale také určité mezery, jejichž zaplnění se nabízí a je výzvou pro budoucí badatele. Materiál k tomu mohou poskytnout nejnovější poznatky například z oblasti psychologie, neurologie či kognitivních věd.

\section{Bibliografie}

ABÉLÈS, Marc. 2004. Politika jako divadlo [Politics As Theatre]. In Petr Skalník. Politická kultura: antropologie, sociologie, politologie [Politic Culture: Anthropology, Sociology, Politology]. Praha: Set out, 2004: 19-42.

ALEXANDER, Jeffrey C., Bernhard GIESEN a Jason L. MAST (edd.). 2006. Social performance: symbolic action, cultural pragmatics, and ritual. Cambridge: Cambridge University Press, 2006. Cambridge Cultural Social Studies.

BERGER, Peter L. a Thomas LUCKMANN. 1999. Sociálni konstrukce reality: pojednáni o sociologii véděni [Social Construction of the Reality: Essay on Sociology of the Cognition]. Brno: Centrum pro studium demokracie a kultury, 1999.

BÍLEK, Petr A. a kol. 2016. Stopy pragmatismu. Česká literatura a estetika v dotyku s americkým pragmatismem [Traces of Pragmatism. Czech Literature and Aesthetics in Touch With American Pragmatism]. České Budějovice: Jihočeská Univerzita - Episteme, 2016.

BLUMER, Herbert. 1969. Symbolic Interactionism: Perspective and Method. Englewood Cliffs, N.J.: Prentice-Hall, 1969.

BLUMER, Herbert. 1998. Symbolic interactionism: Perspective and Method. Berkeley: University of California Press, 1998.

BOGATYREV, Petr. 1940. Lidové divadlo české a slovenské [Czech and Slovak Folk Theatre]. Praha: Fr. Borový, 1940: 30-52.

COOLEY, Charles Horton. 1902. Human nature and the social order. New York: C. Scribner's Sons, 1902.

ČAPEK, Karel. 1918. Pragmatismus, čili, Filosofie praktického života. [Pragmatism or The Philosophy of Practical Life]. Praha: F. Topič, 1918.

ČAPEK, Karel. 2000. Pragmatismus, čili, Filosofie praktického života [Pragmatism or The Philosophy of Practical Life]. Olomouc: Votobia, 2000.

FISCHER-LICHTE, Erika. 2005a. „Ach, takové staré otázky...“ a jak s nimi zachází divadelní teorie dnes [„Oh, so old questions...” And How Theatre Theory Treats Them Today]. Divadelni revue 16 (2005): 2: 3-11.

sledních letech se východiska symbolického interakcionismu, potažmo filozofického pragmatismu objevují v již zmíněné kulturní pragmatice Jeffreyho Alexandera. Tento vliv je u něj patrný už v samotném důrazu na symbolické jednání, na to jak je v rámci kulturních performancí manipulováno s významy, ale také v důrazu na úspěšnost či neúspěšnost kulturní performance (ALEXANDER 2006). 
FISCHER-LICHTE, Erika. 2005b. Divadelnost/teatralita a inscenace [Theatricality And Performance]. In Jan Roubal (ed.). Souřadnice a kontexty divadla: antologie současné nèmecké divadelní teorie [Coordinates and Contexts of Theatre: Anthology of Contemporary German Theatre Theories]. Praha: Divadelní ústav, 2005: 129-134.

GOFFMAN, Erving. 1999. Všichni hrajeme divadlo: sebeprezentace v každodenním životě [The Presentation of Self in Everyday Life]. Praha: Nakladatelství Studia Ypsilon, 1999.

HÖFFDING, Harald a Josef KRÁL. 1947. Přehledné dějiny filosofie [History of Philosophy Overview]. Praha: Česká grafická Unie, 1947.

HORVÁTH, Martin. 2008. Herbert Blumer: Symbolický interakcionismus - teoretické a metodologické vymezení [Herber Blumer: Symbolic Interactionism - Theoretical and Methodological Definition]. In Jiř́ Šubrt (ed.). Soudobá sociologie II (Teorie sociálniho jednáni a sociálni struktury) [Contemporary Sociology II (The Theory of Social Interaction and Social Structures)]. Praha: Nakladatelství Karolinum, 2008: 35-61.

HROCH, Jaroslav. 2003. Soudobá anglo-americká a kanadská filosofie [Contemporary Anglo-American and Canadian Philosophy]. Brno: Filosofická fakulta Masarykovy univerzity Brno, 2003.

CHARON, Joel M. 2010. Symbolic interactionism: an introduction, an interpretation, an integration. Boston: Prentice Hall, 2010.

JAMES, William. 1918. Pragmatism. Praha: Jan Laichter, 1918.

JAMES, William. 1952. The Principles of Psychology. Chicago: Encyclopaedia Britannica, 1952.

JEVREJNOV, Nikolaj. 2014. Scénické ztvárnění života. Ex cathedra [Theatricalization of life. Ex Cathedra]. Theatralia 17 (2014): 1: 119-148.

KAREL, David. 2010. Interakční symbolismus a sociální konstruktivismus: interpretační model lidského jednání [Interactive Symbolism and Social Constructivism: Interpretative Model of Human Action]. In Pedagogické a psychologické discipliny v př́pravě pracovnikư v sociální sfére: sbornik z mezinárodni konference konané dne 21. 4. 2010 na Pedagogické fakultě UJEP v Ústí nad Labem [Paedagogic and Psychologic Disciplines in Social Workers Training: Proceedings From an International Conference, Paedagogical Faculty, Jan Evangelista Purkyně University, Ústí nad Labem, 21 Apr 2010]. Ústí nad Labem: Pedagogická fakulta Univerzity J. E. Purkyně, 2010.

KARGER, Tomáš. 2010. Srovnání metodologických východisek H. Blumera a C. Geertze [Comparing the Methodologies of Herbert Blumer and Cliford Geertz]. Bakalářská práce [BA Thesis]. Filozofická fakulta Univerzita Palackého. Olomouc: Univerzita Palackého, 2010.

KOTTE, Andreas. 2010. Divadelni věda [Theatre Studies]. Praha: Nakladatelství KANT, 2010.

MEAD, Georg Herbert. 2017. Mysl, Já a společnost [Mind, Self, and Society]. Praha: Portál, 2017.

MORRIS, Charles W. 1997. Základy teorie znaku [Basic Theory of Sign]. In Bohumil Palek. Sémiotika [Semiotics]. Ch. S. Peirce, C. K. Ogden \& I. A. Richards, Ch. W. Morris, H. B. Curry. Praha: Karolinum, 1997: 197-265.

PALEK, Bohumil. 1997. Sémiotika [Semiotics]. Ch. S. Peirce, C. K. Ogden \& I. A. Richards, Ch. W. Morris, H. B. Curry. Praha: Karolinum, 1997.

PAUL, Arno. 1971. Theaterwissenschaft als Lehre vom theatralischen Handeln. Kölner Zeitschrift für Soziologie und Sozialpsychologie 23 (1971): 1: 55-57.

PAUL, Arno. 2005. Divadelní věda jako nauka o divadelním jednání [Theatre Studies as a Research on Theatre Acting]. In Jan Roubal (ed.). Souradnice a kontexty divadla. Antologie současné německé divadelni teorie [Coordinates and Contexts of Theatre: Anthology of Contemporary German Theatre Theories]. Praha: Divadelní ústav, 2005. 
PLESSNER, Helmuth. 2008. K antropologii herce [To the Anthropology of Actor]. Disk 24 (červen, 2008): 21-28.

PODHOROVÁ, Miluše. 1980. Symbolický interakcionismus, výklad a kritika [Symbolic Interactionism: Discourse and Critique]. Brno, 1980. Diplomová práce [Final Thesis]. Filozofická fakulta univerzity J. Ev. Purkyně v Brně. Vedoucí práce [Tutor] Miroslav Ovesný.

ROUBAL, Jan (ed.). 2005. Souřadnice a kontexty divadla. Antologie současné německé teorie [Coordinates and Contexts of Theatre: Anthology of Contemporary German Theatre Theories]. Praha: Divadelní ústav, 2005.

ROUBAL, Jan. 2010. Interaktivita jako dimenze teatrality života a živosti divadla [Interactivity as A Dimension of the Theatricality of Life and Liveliness of Theatre]. In Ad honorem prof. PhDr. Ivo Osolsobě. Tendence v současném myšleni o divadle [Ad Honorem Prof. Ivo Osolsobě. Tendencies in Current Thinking About Theatre]. Sborník z konference Divadelní fakulty Janáčkovy akademie múzických umění v Brně [Conference Proceedings, Theatre Faculty, Janáček Academy of Performing Arts]. Brno: JAMU, 2010: 126-153.

SAUSSERE, Ferdinand de. 1989. Kurs obecné lingvistiky [Course of General Linguistics]. Praha: Odeon, 1989.

SINGER, Milton. 2003. Search for Great Tradition in Cultural Performances. In Philip Auslender (ed.). Performance. Critical Concepts in Literary and Cultural Studies. London/New York: Routledge, 2003: 57-71.

SMITH FISCHER, Iris. 2013. Theatre at the Birth of Semiotics: Charles Sanders Peirce, François Delsarte, and Steele Mackaye. Transaltions of the Charles SS. Peirce Society 49 (2013): 3: 371-394.

ŠUBRT, Jiří. 2008. Soudobá sociologie II. [Current Sociology II]. Praha: Karolinum, 2008.

THOMAS, William Isaac a Dorothy Swaine Thomas THOMAS. 1928. The child in America: behavior problems and programs. New York: A. A. Knopf, 1928.

TURNER, Victor a Edith TURNER. 1982. Performing Ethnography. The Drama Revue: TDR. 26 Intercultural Performance (Summer, 1982): 2: 33-50.

TURNER, Victor. 1980. Social Dramas and Stories about Them. Critical Inquiry 7 On Narrative (Autumn, 1980): 1: 141-168.

VIŠŇOVSKÝ, Emil. 2014. Nové štúdie o pragmatizme Ẽ neopragmatizme [New Studies on Pragmatism and Neopragmatism]. Bratislava: Veda, 2014: 274.

VOROVKA, Karel. 1929. Americká filosofie [American Philosophy]. Praha: Sfinx, Bohumil Janda, 1929. 


\section{Mgr. Lukáš Kubina}

Katedra divadelních studií

Filozofická fakulta, Masarykova univerzita, Brno

lukas.kubina@mail.muni.cz

Mgr. Lukáš Kubina v současné době působí jako doktorand na Katedře divadelních studií FF MU. Ve svém výzkumu se především zajímá o interdisciplinární přesahy do sociokulturní antropologie a sociologie, a o teatralitu veřejných událostí. Studijně strávil semestr na University of Warsaw v Polsku a na University of Bergen v Norsku. Je spoluorganizátorem mezinárodní letní školy Jaroměř-Josefov Summer School.

Lukáš Kubina is currently studying for his Ph.D. Degree at the Department of Theatre Studies, Faculty of Arts, Masaryk University. His research interests comprise the interdisciplinary issues of Theatre, Anthropology, and Sociology, especially the theatricality of public events. Kubina spent a study term at the University of Warsaw, Poland, and the University of Bergen, Norway. Kubina has co-organized the International Summer School of Performativity in Jaroměř-Josefov.

\section{Doc. Mgr. Martina Musilová, Ph.D.}

Katedra divadelních studií

Filozofická fakulta, Masarykova univerzita, Brno

martina-musilova@seznam.cz

Doc. Mgr. Martina Musilová, Ph.D. (1969) vystudovala divadelní vědu na Filozofické fakultě Karlovy univerzity v Praze (doktorská práce obhájena 2007, 2011 publikována pod názvem Fauefekt. Vlivy Brechtova epického divadla a zcizujícího efektu v českém moderním herectví). Při studiu navštěvovala na DAMU kurzy Ivana Vyskočila "Dialogické jednání s vnitřním partnerem". Od r. 1999 působí jako asistentka Ivana Vyskočila, od r. 2009 vyučuje na Katedře divadelních studií Filozofické fakulty Masarykovy univerzity v Brně a od r. 2013 také na Katedře teorie a kritiky DAMU. Ve svém výzkumu se specializuje na historii a teorii herectví a na teatralitu veřejných událostí.

Martina Musilová (1969), graduated in theatre studies from the Faculty of Arts at Charles University in Prague, where she successfully defended her thesis in 2007 (published in 2011 under the title Fauefekt. Vlivy Brechtova epického divadla a zcizujicího efektu $v$ českém moderním herectvi). During her university studies she attended Professor Ivan Vyskočil's lectures of Dialogical Acting with the Inner Partner at AMU's Theatre Faculty in Prague. Since 1999 she has been working as an assistant of this discipline. Since 2009 she has been lecturing at the Department of Theatre Studies at the Faculty of Arts at Masaryk University in Brno and since 2013 also at the Department of Theory and Criticism at AMU's Theatre Faculty in Prague. She specializes in the history and theory of acting and the theatricality of public events. 